\title{
Exploring practicum: student teachers' social capital relations in schools with high numbers of pupils living in poverty
}

\section{Archie Graham, Lindsay MacDougall, Dean Robson \& Peter Mtika}

\section{University of Aberdeen}

\begin{abstract}
The complexity of practicum in Initial Teacher Education, in terms of the range of diverse social relations and differing school contexts, provides a challenge for teacher educators worldwide, aiming to guide and shape opportunities for student teachers learning to teach. This challenge is further compounded by societal problems linked to child poverty. Drawing from social capital theory, this paper explores the kinds of social relations that are currently associated with student teachers' practicum experience in schools located in areas of social and economic deprivation or with significant proportions of pupils living in poverty. The paper surfaces types of social relations that are beneficial to mitigating the effects of poverty on educational outcomes. The case is made that practicum does not currently support the principles of social capital theory by enabling student teachers to develop an understanding of how to make connections, and develop the social relationships required to support positive educational outcomes for the children and young people in such contexts. Findings indicate that more effective 'joint practice' is required to better support student teachers' professional learning.
\end{abstract}

Key words: practicum, student teachers, social capital, poverty

\section{Introduction}

Globally, the period of school-based teaching practice undertaken by student teachers, known as practicum, is a central feature in the design of Initial Teacher Education (ITE) 
programmes. Cohen, Hoz \& Kaplan (2013) in their analysis of studies on practicum in many countries, identify: student teachers' professional growth, familiarisation with the teacher's real role, the school's environment, and student teachers' developing understanding of the cultural diversity of pupils as main goals for practicum. Based on a systematic review, Cochran-Smith, Villegas, Abrams, Chavez-Moreno, Mills, \& Stern (2015) highlight the complexity of practicum internationally, in terms of social practices, structures, tensions among participants, candidate characteristics and differing school contexts that influence and shape opportunities for learning to teach. Similarly, Lawson, Cakmak, Gündüz \& Busher's (2015) found in their systematic review that practicum in different countries, spans a wide range of educational settings making it difficult to identify patterns in practicum outcomes due to the differing cultural and educational contexts.

In 'advanced' economies, societal problems linked to child poverty and socio-economic deprivation present challenges to current ways of working for teacher educators and their students. The phenomenon of an inequality gap, politically reconstituted as an 'attainment gap' (Thomson, 2015) underscores this challenge as evidenced by the disproportionate number of young people growing up in poverty and socio-economic deprivation. Many of these young people fail to achieve positive educational outcomes in contrast to their peers living in more affluent conditions (Sosu \& Ellis, 2014). However, student teachers can make a positive contribution to the lives of these young people (Gilroy, 2016), but there is a need to further develop ITE to prepare new teachers for ways of working that transcend the walls of the classroom. For example, Burn and Childs (2016) report on the success of their ITE programme in England, which supports their students to undertake an enquiry into the use of the Pupil Premium Grant. Similarly, in New Zealand, Grudnoff, Haigh, Hill, Cochran-Smith, 
Ell \& Ludlow (2016) report that having a specific focus on equity in ITE contributed to their students feeling better prepared to work in schools located in low socio-economic communities. They (ibid) also highlight the importance of strengthening their ITE programme through further focus on the effects of poverty on children's learning. In the United States, Kretchmar and Zeichner (2016) call for ITE to focus on the relational preparation of their students to enable them to understand and care for the communities in which they serve, becoming more connected to wider efforts to address inequalities, through relational approaches.

While recognising that ITE alone will not solve the attainment problems related to child poverty and socio-economic deprivation, this paper will examine the kinds of social relations that are currently associated with student teachers' practicum experience in schools located in areas of social and economic deprivation or with significant proportions of pupils living in poverty. It draws on the conceptual framework of social capital theory to mobilise resources and knowledge, (Baron, Field, and Schuller, 2000) available to student teachers through the social relationships they develop during practicum. It aims to explore the types of social relations which support student teachers' efforts in mitigating the effects of poverty on the educational outcomes of the pupils they work with.

\section{Background: child poverty and educational outcomes}

In many countries, the likelihood of educational failure for children and young people living in poverty and deprivation is a complex, challenging, and persistent societal problem. Across the western world, high levels of poverty and deprivation have been shown to be damaging to children and their educational outcomes (e.g. Boston, 2014; Bradshaw, 2011; Goodman and Gregg, 2010; Kiernan and Huerta, 2008). For example, in the UK, despite the school 
improvement work of the last 30 years, Hargreaves (2014, p. 607) notes that, 'the gap between free school meals (FSM) children and others has barely shifted and schools in the most disadvantaged area are amongst the slowest to improve (Ofsted, 2013)'. Crucially, the complex and broad nature of the problem of child poverty and deprivation in relation to educational experiences, cannot be addressed by schools alone. This insight raises equally crucial questions about what must constitute suitable professional preparation for new teachers alongside other professional groups serving children and families in poverty. As Nixon (2015) points out,

Almost all the problems we now face are collective problems: bigger-than-selfproblems that require both collective and global understanding... Such problems can only truly be addressed through multilateral discussions. (Nixon, 2015, p. 1)

Applying Nixon's insight to the issue of suitable professional preparation for new teachers, opens possibilities to whole-scale ITE system changes that explore new relational approaches that reach out beyond schools and education. Recognising that such change has broader implications for other child sector professional groups, the authors also recognise that the examination of change beyond ITE is outwith the scope of this paper.

\section{Working with others as part of ITE}

Working with others is a key idea associated with the professional learning, growth, and development of teachers. In Scotland, the focus country in this paper, the General Teaching Council for Scotland (GTCS) sets professional standards for pre-service and fully qualified teachers. Student teachers are expected to, 'demonstrate an ability to work co-operatively in the classroom and the wider learning community with staff, parents and partner agencies to promote learning and wellbeing' (GTCS, 2012, p. 15) and, 'work collaboratively to share 
their professional learning and development with colleagues' (GTCS, 2012, p. 20). Like Nixon's (2015) insight (above), the GTCS standards recognise the need for student teachers to adopt a relational approach to fulfil their professional responsibilities.

This echoes with recommendations from the Teaching Scotland's Future (TSF) Report (Scottish Government, 2011a) which purports that teacher education in Scotland should foster a culture of professional learning and collaboration. The Scottish Government, in accepting the recommendations emerging from TSF (ibid), signalled its commitment to collaborative ways of working, albeit, in this case, the development of more integrated relationships between University providers of teacher education and schools. However, the TSF report has been critiqued by Forbes \& McCartney (2012) for its 'mono-professional' framing and disconnect from wider public service policies (e.g. Scottish Government, 2011b) that call for inter-agency working and collaboration between public services. Moreover, not all teacher collaborations are equal or equally productive (Ronfeldt, Farmer, McQueen, and Grissom, 2015) and there have been calls for such relationality to be expanded to develop student teachers' (i) knowledge for teaching (Darling-Hammond, 2016) and (ii) capacity to produce knowledge for teaching that is sensitive to their working context (Beckett, 2014).

A key message emerging from the policy context in Scotland centres on delivering integrated public services through inter-agency working. The independent report by the Christie Commission (Scottish Government, 2011b) on the delivery of public services in Scotland forewarned that, 'Unless Scotland embraces a radical, new, collaborative culture throughout our public services, both budgets and provision will buckle under the strain.' (Scottish Government, 2011b, p. viii). The importance of such collaboration is further underscored by 
the national approach to improving outcomes and supporting the wellbeing of children and young people in Scotland, Getting it Right for Every Child (GIRFEC) (Scottish Government, 2012) which promotes collaboration between public services and partnerships with parents by placing the rights and wellbeing of children and young people at the centre.

Internationally, teachers are increasingly expected to proactively support pupils and their families, making appropriate early interventions at the first signs of any difficulties, rather than responding once a situation has escalated. Yet in Scotland and other parts of the world, despite these efforts, inequalities between children and young people living in poverty and deprivation, and their more affluent peers persist. In part, we would suggest, continued inequality may be linked to the apparent anomaly, highlighted by Forbes \& McCartney (2012), that ITE itself is not sufficiently well integrated in cross-sector working across all children's public-sector services.

\section{Social Capital Theory}

Social capital theory can be viewed in its broadest sense as the means to access resources and knowledge embedded in social relationships (Baron, Field, and Schuller, 2000). Social capital enables people to mobilise embedded resources to facilitate action (Coleman, 1988). For Putman (2000:19), 'social capital refers to the connections among individuals - social networks and the norms of reciprocity and trustworthiness that arise from them'. The concept of social capital has roots in social theory (Bourdieu, 1986) and in the social context of education (Coleman, 1988). From a social capital perspective successful working together emerges from connections and relationships, and such relations are the key focus of this paper. 
There is consensus in theory that social capital comprises three key features: networks, norms and trust. In addition, these key features have been further categorised by the Office for National Statistics (ONS), 2002 as bonding, bridging or linking (Table 1), and a three-point scalar frame (macro, meso and micro) has been used to delineate different levels at which social capital works (Halpern, 2005). The multi-scalar conceptual frame has been successfully applied in different contexts (e.g. Forbes, 2010; Forbes and McCartney, 2010; McKean, Law, Laing, Cockerill, Allon-Smith, McCartney \& Forbes, 2017).

In this paper we use Forbes \& McCartney's (2010) analytical framework for social capital (Table 1), and reflect on its application for exploring practicum, the main analytical focus of this paper. As practicum operates at the meso level (school level), Forbes and McCartney's analytical framework offers the means to explore the bridging and linking social relations between the student teachers and others in our research. Applying a social capital analytical framework, we are alert to the potential negative side of social capital whereby high levels of bonding social capital relations, for example, can lead to the exclusion of outsiders (in this case, non-teaching professional groups) and produce potential tensions among different groups (Arneil, 2006).

[Insert Table 1 near here]

Forbes \& McCartney's (2010) analytical framework for social capital provides a way of exploring and reflecting on school-level based relations between student teachers and other practitioners during practicum.

\section{The study}


To reiterate, the purpose of the study reported here is threefold: (i) to explore the kinds of relations that are currently associated with student teachers' practicum experience in schools located in areas of social and economic deprivation or with significant proportions of pupils living in poverty, (ii) to identify which types of relations are beneficial to mitigating the effects of poverty on educational outcomes and (iii) to reflect on how to better support student teachers professional learning and preparation to address inequality associated with child poverty and deprivation. The approach used was developed by a teacher educator research group in a Scottish university aiming to understand how student teachers might be supported better to work with children and young people living in poverty. In Scotland, areas of social and economic deprivation are identified using the Scottish Government's (2016) Scottish Index of Multiple Deprivation (SIMD). The Scottish Educational Research Association (2005) ethical guidelines were adhered to throughout.

\section{The Research Participants}

The five student teachers who voluntarily participated in this study were enrolled on a Professional Graduate Diploma in Education (PGDE), one-year ITE programme, at a Scottish University. Their practicum experience consisted of two nine-week placements in two different schools. Each nine-week practicum was split into two blocks of 5 weeks and 4 weeks. At the time of the interviews the research participants had completed five weeks of their second practicum placement. During the interviews the research participants focused on their current practicum placement, but often made comparisons with their first.

The criteria for locating and recruiting the research participants were guided by three principles (Cohen, Kahn, and Steeves, 2000): (i) their experiences of place, here defined as 
schools located in areas of social and economic deprivation or in schools with significant proportions of pupils living in poverty, (ii) their experiences of events in time, here defined as the period of practicum during ITE, and (iii) ways of talking about their experiences, with a focus on ITE. Therefore, purposive sampling was adopted. Table 2 provides a summary sketch of each participant, using pseudonyms.

[Insert Table 2 near here]

\section{Methodology}

The study employs a hermeneutic phenomenological reflection (van Manen, 1990). The evidence for the study is derived from five first-person reports of the lived experiences of the participating student teachers. These accounts were collected through semi-structured conversational interviews designed to gather fragments of the participants' experiences of their practicum in schools located in areas of social deprivation or in schools with significant proportions of pupils living in poverty.

Semi-structured interviews, consisting of a series of questions and prompts, were used, aiming to ensure consistency of implementation by the researchers. This technique provided sufficient flexibility enabling interviews to unfold as conversations, allowing for the exploration of each participant's lived experience of practicum. Five interviews, each lasting approximately 50 minutes, took place. All were audio-recorded and fully transcribed by the researchers enabling engagement with data analysis and interpretation during the data collection phase. The creation of the interview transcripts provided the text for subsequent isolation of thematic aspects of the participants' lived experiences. Drawing from the work of van Manen (1990), two methods for approaching the data in the transcripts were utilised: 
'wholistic' (or sententious) and 'detailed' (line by line). This enabled a good balance between part and whole reading.

Once an understanding of the overall text had been grasped for each of the five transcripts, natural meaning units (NMUs) were isolated, each containing a single meaning, borrowing from the approach used in descriptive phenomenology (Devenish, 2002). The identified NMUs were numbered to enable each transcript to be navigated and cross referenced. Researchers read and re-read this version of the transcript line by line to identify tentative interpretive themes and experiences in the text. These were labelled, and extraneous items were removed. Common links were then identified between the emergent themes, and these linked themes were then clustered to produce eight explicative themes spanning the five transcripts. Each explicative theme is presented in Table 3 and is illustrated with quotations from the participant interviews.

\section{[Insert Table 3 near here]}

These explicative themes capture a sense of the meaning the participants attribute to their lived experiences of working in schools located in areas of social deprivation or with significant proportions of pupils living in poverty. These data were then analysed further through conversation (Gadamer, [1975] 2006: 385) with key themes from the analytical framework for social capital. By conversation, Gadamer refers to the process of being challenged to go beyond our existing horizons to be able to understand the other. This involved bringing the horizons of the researchers (see social capital analytical framework above) into conversation with the horizons of the research participants as found in the interview transcripts. Table 4 shows how the features of social capital link to the explicative themes elicited in this study. Our findings are outlined below with illustrative quotations. 
[Insert Table 4 near here]

\section{Findings}

Norms and Values

The student teachers' experiences of practicum, in schools in areas of social and economic deprivation or with significant proportions of pupils living in poverty, provide evidence of school practitioners pulling together to support each other to get through the day. There was little evidence of joint problem solving with and around the pupil, or of support for pedagogy; rather practicum data highlights support for classroom management and maintaining staff morale.

The thing I found most amazing out there was that the teachers really pulled together. There was a lot of support for each other. The only thing I would say was that it wasn't necessarily in the teaching, but there was a lot of understanding a lot of support for managing the kids.... There was support but not ideas of what to do. Everybody was really understanding and didn't judge you and made you feel welcome, but at the same time there wasn't the input of how to improve, or what to do. (Mary)

Student teachers also exhibited a tacit understanding of the need to build positive relationships with the pupils in their classes and adopted practices to support this aim.

I try not to treat anyone any differently from anyone else. Your class is your class, and you try not to, but you still need to be aware and to keep an extra eye on some kids and if they're struggling that bit more. (Rita) 
The student teachers' awareness of the need to build positive relationships with their pupils is reinforced by their awareness that if they (student teachers and pupils) are to work together productively they must develop relations of trust.

\section{Trust and reciprocity}

While the length of the second practicum was perhaps too short (two blocks: 5 weeks and 4 weeks) for trust to be fully established between the student teachers and professionals in the practicum schools, all student teachers appreciated the need for them to begin to build positive and trusting relationships with their pupils. As Kayla states,

It's the relationships between pupil and teacher which are really, really, important for me. It is really important to build up that trust and in some respects with some difficult children that I've worked with the last, the last couple of placements, it has really proved to work well ... some people have really shown some huge improvement which I never thought I could see and resistance to learning from the beginning and you think well okay how's this going to work?

Thus, Kayla understands the development of trust to be integral to finding ways of working that are mutually beneficial to the pupils and the student teacher.

Bonds, bridges and links

In our analysis we could find no evidence of bonding involving the student teachers. This is not surprising as the student teachers did not know the staff in the schools prior to the start of their practicum and there was insufficient time for strong bonds to develop. However, there was evidence that they had observed bonding in experienced teachers.

There was a teacher that took the nurture group at the school and she was brilliant... She really, really knew them well, listened to them ... very understanding. (Elsa) 
There was evidence of bridging and linking bonds that operated at the macro, meso and micro levels.

Bridges (Macro (policy) and Meso (school) Level)

In the case of Amelia, she was aware of the national policy, Getting it Right for Every Child (Scottish Government, 2012) which aims to improve the outcomes and to support the wellbeing of children and young people through early intervention by the right children's sector professionals at the right time. However, Amelia experienced minimal contact with other professionals from other agencies.

There was involvement with GIRFEC and there was also a social worker, a residency social worker, in the school. There were also police in school, so there is involvement with the community. (Amelia)

Amelia demonstrates knowledge of other school level professionals' co-work on site and that this co-practice arrangement derives from recommendations and prescriptions on children's sector co-practice in macro-level policy: GIRFEC. Awareness of other professionals from other agencies was also evident in the lived experiences of other student teachers.

\section{Bridges (Meso Level)}

In Elsa's practicum school there was a policy of early intervention aiming to help deter young people from engaging in risky behaviours.

They had a police officer come in. He did work about drug and alcohol abuse. They also had the school nurse come in to do the sex education stuff...em... I didn't see speech and language or educational psychologist or anything like that... They had a Family Support worker and she used to be a nurse but then had moved into this role so spoke to her a couple of times. 
As a student teacher, Elsa had minimal contact with these professionals and no contact with allied health professionals such as speech and language therapists or educational psychologists. However, Kayla speaks of student teachers participating in professional development opportunities with the teachers in their practicum schools.

Some staff from our school went to Tapestry meetings [Professional development for teachers and other professionals who work with children and young people] then came back and did a session with us, so I was actually lucky enough to be involved, in three Tapestry sessions and it was looking at the attainment, the funding and things like that. (Kayla)

While Kayla welcomed the opportunity to work with other teachers beyond her teacher mentor, having the experience was fortuitous as the event coincided with Kayla's period of practicum. Aware of the benefits of building bridging relations Kayla also demonstrated initiative in terms of making connections with a local charity for the benefit of her pupils.

I firmly believe that working with charities such as Charity $Y$ [a Christian charity, with international reach] they have that resource on their doorstep... there is so much they could do with it because they actually provide training to the kids... that day it was in moving and handling... they got a certificate at the end of the day... something as simple as that but they feel, 'oh wow I got a certificate'. It's celebrating their achievements in a different way and I think they offer retail qualifications and that gives them experience of admin. The focus is maybe slightly away from academia but it's necessary skills and it is still literacy and it is still numeracy. It feeds into the Curriculum for Excellence [the national curriculum for Scottish schools]. (Kayla)

In taking opportunities to bridge across to a local charity beyond the physical practicum school boundaries, Kayla sought to build positive student teacher/pupil relationships and 
importantly to widen her pupils' stocks of bridging social capital beyond school, into the charity sector of society. Equally, Kayla celebrated her pupils' achievements of new knowledge and skills in the arena beyond school, something not all schools or teachers might do. Kayla, a student teacher, thereby drew on her own context specific practical problemsolving knowledge (Forbes, \& McCartney 2012) to successfully undertake a context specific initiative for her pupils beyond the school walls. This student teacher initiated a context specific response to address the needs of the pupils in her care.

\section{Bridges (Micro Level)}

We found some evidence of student teachers building cross-cutting ties with other practitioners in the school at the micro level of inter-personal knowledge and skills relations. For example, Mary sought to include pupils whose first language was not English, interacting with the teacher of English as an Additional Language (EAL), to clarify a classroom issue utilising the EAL teacher's translation knowledge and skills, an example of successful student/EAL micro-level bridging relation.

I worked with PSAs, [Pupil Support Assistants] but there was also the EAL teacher and this helped. The EAL teacher helped with translations, but we could not use her all the time. When she did translate for an EAL child it was the only time we had a clear understanding of what he wanted to say and I think that was incredibly important. It was helpful when there were issues, for example, the class had accused him of something and it was clear that he had done it when the EAL teacher translated. I would have liked to have gone deeper and have had some proper conversations with him. (Mary)

\section{Links (Macro Level)}


Lack of opportunity for student teachers to learn to work with professionals from other agencies was evident, we found, in student teachers' efforts to follow school policy on child protection.

I brought up four different child protection issues in my last four weeks of placement. The staff are kind of like... but half the time I don't think they mean anything by it ... and I'm like ah... there's a couple of things there that just because they are from a poor background does not mean you should ignore a lot of the things that they say ... perhaps there is some truth in some of the things they say." (Kayla)

Kayla may have been overzealous or had identified and brought to the attention of senior management genuine child wellbeing issues. Nevertheless, this excerpt does point to the need for more pre-practicum preparatory work on the sensitivity of child protection and interagency collaborative working to help students, like Kayla, make sense of the complexities of practicum school environments.

\section{Links (Meso Level)}

In other data, Kayla demonstrates initiative in pursuit of her aim to build trust with her pupils beyond the walls of the classroom to make linking relationships up and down levels of the school 'organisational hierarchy'.

Going into the community wing and kind of seeing the work that they do ... sitting and chatting to some of the kids in a different setting ... so it's getting outside the classroom and finding out how these kids tick in other ways and maybe finding out these... and that was really rewarding... because it paid off in the classroom. They see you in a different context as well... I think it is really important for that to happen. Building relationships is really important. (Kayla) 
Similarly, to find out more about the school's environment, Amelia sought links upwards in the school hierarchy with one of the depute head teachers in her practicum school.

One of the depute heads explained to me that having the police in the school would help in that the kids wouldn't be afraid of the police. (Amelia)

\section{Links (Micro Level)}

The links upwards and downwards across the organisation emerging from the student teacher micro-level data are located in two categories: (i) knowledge and understanding of the diversity of pupils; and, (ii) knowledge and understanding of the wider role of the teacher.

\section{Familiarisation with the diversity of pupils}

To familiarise themselves with the diversity of pupils the student teachers spoke with their mentor teachers. However, the student teachers recount receiving only partial information, and being left to work the rest out for themselves.

You don't get told very much but you're kind of given a generalisation. (Rita)

Therefore, to gain a clearer understanding of the diversity of the pupils, Amelia sought links with other members of practicum school staff.

So it's just the fact of understanding the situation of pupils, talking with mentor teachers, talking with guidance teachers being aware, so I would say to others, being aware of their situation as much as possible. (Amelia)

The ITE students are preparing to become teachers. Mentors may be motivated by loyalty to children and families to maintain confidentiality; or, for example, mentors may wish children to have a fresh start with student teachers. However, the data reveal that mentors' full knowledge of the class is not shared with the student teachers; incidences of lack of trust 
between teacher mentors and student teachers in practicum schools may have potential implications for pupils and those responsible for them on practicum.

Familiarisation with the wider role of the teacher

The student teachers also sought opportunities to enhance their knowledge of, and to familiarise themselves with, the wider role of the teacher, but the data show that their experiences were often peripheral, as when adopting the role of observer.

I sat in on the parents' evening. That's the only contact I had with them. It was okay but, very poorly attended, I remember sitting with the teacher before the parents' night and we sort of identified who we would really like to speak to ... and not one of them came or didn't even book an appointment in some cases. If the parents don't want to come in, you can't force it but I think that's even as widening the attainment gap further ... because the ones that come in get extra support. (Elsa)

These examples illustrate some of the challenges faced by student teachers during their practicum experiences in schools located in areas of social and economic deprivation or with significant proportions of pupils living in poverty. The social practices as perceived by the student teachers in this study point to underdeveloped, or yet to be developed, aspects of practicum that might be explored further by teacher educators as a means to support student teachers develop context specific responses that are sensitive to the nuances of each school's environment.

\section{Discussion}

In our investigation into the lived experiences of student teachers during their second nineweek practicum, we aimed to explore the kinds of relations that are currently associated with 
student teachers' practicum experience in schools located in areas of social and economic deprivation or with significant proportions of pupils living in poverty. We found that the student teachers engaged in networks of complex relations that primarily centred on familiarisation with: the teacher's real role, the school's environment, and the cultural diversity of pupils, which is in keeping with the findings of Cohen, et al., (2013) in their analysis of studies on practicum. However, as indicated above, the duration of the practicum appears to be on the short side if more meaningful relationships are to be developed. Further research is necessary to explore the possibilities and limitations of different lengths of practicum in terms of the types of meaningful social capital relationships that can be fostered by student teachers.

We also aimed to identify the types of relations beneficial to mitigating the effects of poverty on educational outcomes. Drawing from social capital theory (Putman, 2000; Bourdieu, 1986; Coleman, 1988) we were able to categorise the predominant social relations found in the lived experiences of the student teachers in terms of bridges and links. Teacher-teacher exclusive bonding relations cut out ITE students from potentially important knowledge of the pupils for whom they were partly responsible for on practicum. Using the frame (see Table 1) developed by Forbes and McCartney (2010) we explored evidence of bridges and links at three different levels: macro (policy and governance), meso (schools and other children's institutions), and micro (practitioners' knowledge and skills stocks). In so doing, we established that despite the Scottish Government's GIRFEC policy enjoinders (Scottish Government, 2012) prescribing a new, collaborative culture throughout our public services including children's services, the student teachers had minimal contact with professionals from other agencies, and in most cases no contact with key allied health professionals. These findings are consistent with the findings of Forbes \& McCartney (2012) who highlight a disconnection between teaching and broader public service policies in what constitutes 
collaborative practices. This echoes Kretchmar and Zeichner's (2016) call for ITE to become more connected to wider efforts to address inequalities. Our study, endorses the pressing need for further research insights on the re-design of practicum, planned to properly enable student teachers to gain knowledge and practice relevant co-work skills to equip them to work collaboratively with professionals, specialist teachers such as EAL and importantly practitioners from other children's agencies.

In the study, some student teachers were found to be able to participate in whole school professional development events while others sought bridging opportunities within the wider school community to initiate a context specific response to address the needs of pupils. Some bridged across to other practitioners, on a one-to-one basis, in efforts to understand pupils' diverse needs. However, these positive experiences were context specific and opportunistically seized by these student teachers and, therefore, not experienced by other student teachers. Moreover, not all student teachers have the confidence (trust in themselves in social capital terms) and skills, to initiate such unplanned reaching out types of bridging relations to other professionals/practitioners.

In keeping with our third aim, we were able to reflect on how to better support student teachers' professional learning and preparation to address inequality associated with child poverty and deprivation. Our analysis of student teachers' lived experiences of practicum suggests that these ITE students would have benefited from pre-practicum learning on building professional relationships at meso (cross-school) and micro (knowledge and skills relations) levels. Uncovering this ITE knowledge and skills gap, points to a potentially fruitful space for teacher educators to more fully equip student teachers with the necessary 
social capital relations, knowledge, and skills that they will need for their co-work during practicum.

We found that some student teachers sought to develop links with different organisational levels, characterised by differing levels of power at play (Office for National Statistics, 2002). The nature of the student teacher practicum experience positions the student towards the bottom of the school hierarchy. The lowly positioning of student teachers was most evident in their unsuccessful attempts to access information. All participants in the study testified having to work with partial information about the needs of the pupils they were trying to teach and struggled to gather essential, albeit sensitive, context specific information. It is pertinent to emphasise that student teachers are preparing to become professional teachers yet are not always party to sensitive information. The lack of trusting relations evidenced by teacher mentors and perhaps school management towards student teachers, denying access to potentially important or essential information on children in their care, a practice that may endanger student teachers and pupils merits further investigation by those responsible for practicum arrangements.

Perhaps the most interesting finding concerns the challenges faced by student teachers in their efforts to implement context specific pedagogy beneficial to their pupils. Evident in both the explicative themes and in the analysis of the social relationships, in keeping with GIRFEC (Scottish Government, 2012) and related GTCS (2012) standards on co-working, student teachers attempted to initiate pedagogy characterised by working with others in the classroom and wider learning community. Student teachers' discussions with their mentor teachers seldom focused on joint problem-solving to identify effective pedagogy to support 
the pupils' learning. However, our findings also show participant students desiring to learn more about pupils' individual learning achievements, needs and styles.

We found that while student teachers and their mentors may share opinions and strategies relating to specific pupils in the class, they did not actually work together in the classroom. Solo work in class was reflective of the lived experiences of the student teachers. Such practices, we argue, constitute a form of coordination (Marvin, 1990) and not interprofessional collaboration, which involves joint responsibility and joint problem solving. This finding is consistent with the finding of Ronfeldt, et al. (2015) that not all teacher collaborations are equal or equally productive. Moreover, it further highlights the nature of co-practice relations in schools as an area often very poorly conceptualised and understood by teacher educators and school mentors. This is an underdeveloped area of practicum that urgently needs to be harnessed to benefit pupils and new teachers. For example, in partnership with schools, teacher educators need to identify and create the necessary planned rich opportunities for 'joint practice' that our study has shown to currently be sadly lacking in the early stages of student teachers' practicum experience. However, as research into student teacher mentoring (e.g. Wang, 2001; Mtika, Robson, \& Fitzpatrick, 2014) has shown, there is likely to be a need for teacher educators to understand the school contexts in which practicum takes place to support the design of 'joint practice' and explore the kinds of meaningful learning opportunities that are possible.

\section{Conclusion}

We wish to highlight two key messages from our research for university-based teacher educators aligned with the aim of improving the design of practicum. First, the social capital 
analytical framework (Forbes \& McCartney, 2010) provides valuable analytical concepts and categories, providing critical purchase on how, or how not, student teachers' and practitioners' practicum relations produce beneficial inter-professional social capital. Further applications of this analytical framework would aid teacher educators in framing specific goals for practicum that truly promote the types of relations that are mutually beneficial to student teachers and the pupils, schools, and communities in which they work (Kretchmar and Zeichner, 2016).

Second, the scope of the challenge for ITE students working in schools located in areas of social and economic deprivation, or with significant proportions of pupils living in poverty, are such that further research and insights are now timely to enable full understanding of the effects of working in such contexts for student teachers' personal and professional development. Relatedly, to better sustain students, a focus on supporting student teachers to build bridging social capital at the meso and micro levels merits further investigation. There is a need to better understand the nuances of the networks of social relationships that affect pupils in schools in areas of deprivation, and how these might be realistically re-designed, reconfigured to include student teachers (Nixon, 2015). Crucially, student teachers must be preprepared and taught to be alert to their specific practicum school context. Practicum preparation must encompass the knowledge and skills for student teachers to enact pedagogy, including co-practice, beneficial for pupils living in poverty.

\section{References}

Arneil, B. (2006). Diverse communities: The problem with social capital. Cambridge:

Cambridge University Press. 
Baron, S., J. Field, \& T. Schuller, (Eds). (2000). Social capital: Critical perspectives. Oxford. Oxford University Press.

Beckett, L. (2014). Raising Teachers' Voice on Achievement in Urban Schools in England: An Introduction. The Urban Review, 46(5), 783-799

Bourdieu, P. (1986). The forms of capital. In J.G. Richardson (Ed.), Handbook of theory and research for the sociology of education (pp.241-58). New York: Greenwood.

Boston, J. (2014). Child Poverty in New Zealand: Why it matters and how it can be reduced. Educational Philosophy and Theory, 46(9), 962-988.

Bradshaw, P. (2011). Growing up in Scotland: Changes in child cognitive ability in the preschool years. Edinburgh, Scottish Government.

Burn, K., \& Childs, A. (2016) Responding to poverty through education and teacher education initiatives: a critical evaluation of key trends in government policy in England 1997-2015, Journal of Education for Teaching, 42:4, 387-403.

Cochran-Smith, M., Villegas, A.M., Abrams, L., Chavez-Moreno, L., Mills, T., \& Stern, R. (2015). Critiquing Teacher Preparation Research: An Overview of the Field, Part II. Journal of Teacher Education, 66(2),109-121.

Cohen, M.Z., Kahn, D.L. \& Steeves, R.H. (2000). Hermeneutic Phenomenological Research: A Practical Guide for Nurse Researchers. California: Sage Publications, Inc.

Cohen, E., Hoz, R., \& Kaplan, H. (2013). The practicum in preservice teacher education: a review of empirical studies. Teaching Education, 24(4), 345-380.

Coleman, J.S. (1988). Social capital in the creation of human capital. American Journal of Sociology, 94, 95-120. 
Darling-Hammond, L. (2016). Research on Teaching and Teacher Education and Its Influences on Policy and Practice. Educational Researcher, 45(2), 83-91.

Devenish, S. (2002). An Applied Method for Undertaking Phenomenological Explication of Interview Transcripts. Indo-Pacific Journal of Phenomenology, 2(1), 1-20.

Forbes, J. (2010). Interprofessional capital in children's services transformations. International Journal of Inclusive Education, 1, 1-16.

Forbes, J. \& McCartney, E. (2010). Social capital theory: A cross-cutting analytic for teacher/therapist work in integrating children's services? Child Language Teaching and Therapy, 26(3), 321-334.

Forbes, J. \& McCartney, E. (2012). Educating Scotland's future together? Inter/professional preparation for schools and children's services. Scottish Educational Review, 43(2), 39-54.

Gadamer, H.G. (2006). Truth and Method. (Weinsheimer, J. and Marshall, D.G. trans) London: Sheed, Ward and Continuum Publishing Group. [Original work published 1975]. Gilroy, P. (2016). Editorial, Journal of Education for Teaching, 42(4), 373-373.

Goodman, A. \& Gregg, P. (Eds.) (2010). Poorer Children's Educational Attainment: How Important are Attitudes and Behaviour? York: Joseph Rowntree Foundation [online]. Retrieved from: http://www.jrf.org.uk/sites/files/jrf/poorer-children-education-full.pdf GTCS. (2012). The Standards for Registration: mandatory requirements for Registration with the General Teaching Council for Scotland. Retrieved from: http://www.gtcs.org.uk/web/FILES/the-standards/standards-for-registration-1212.pdf

Grudnoff, L., Haigh, M., Hill, M., Cochran-Smith, M., Ell, F. \& Ludlow, L. (2016) Rethinking initial teacher education: preparing teachers for schools in low socio-economic communities in New Zealand, Journal of Education for Teaching, 42(4), 451-467. 
Halpern, D. (2005). Social Capital. London: Wiley.

Hargreaves, D.A. (2014). A self-improving school system and its potential for reducing inequality. Oxford Review of Education, 40(6), 696-714.

Lawson, T., Çakmak, M., Gündüz, M., \& Busher, H. (2015). Research on teaching practicum - a systematic review. European Journal of Teacher Education, 38(3), 392-407.

Kretchmar, K. \& Zeichner, K. (2016) Teacher prep 3.0: a vision for teacher education to impact social transformation, Journal of Education for Teaching, 42(4), 417-433.

Kiernan, K, E. \& Huerta, M, C. (2008). Economic deprivation, maternal depression, parenting and children's cognitive and emotional development in early childhood. The British Journal of Sociology, 59 (4), 783 - 806.

van Manen, M. (1990). Researching Lived Experience. USA: The State University of New York.

Marvin, C. (1990). Problems in School-based language and collaboration services. Defining the terms and improving the process. Language, Speech and Hearing Services in Schools, $25,258-68$.

McKean, C., Law, J., Laing, K., Cockerill, M., Allon-Smith, J., McCartney, E. \& Forbes J. (2017). A qualitative case study in the social capital of co-professional collaborative copractice for children with speech, language and communication needs. International Journal of Language and Communication Disorders, 52(4), 514-527.

Mtika, P., Robson, D. \& Fitzpatrick, R. (2014). 'Joint observation of student teaching and related tripartite dialogue during field experience: Partner perspectives'. Teaching and Teacher Education, 39 (2014), 66-76.

Nixon, J. (2015) Learning together. New Chalk Talk, 14(9), 1-2. 
Office for National Statistics, (2002). The Measurement of Social Capital in the United Kingdom. London: ONS.

Putman, R. D. (2000). Bowling Alone: The Collapse and Revival of American community. New York: Simon \& Schuster Paperbacks.

Ronfeldt, M., Farmer, S.O., McQueen, K. \& Grissom, J.A. (2015). Teacher Collaboration in Instructional Teams and Student Achievement. American Educational Research Journal, $52(3), 475-514$.

Scottish Government. (2011a) Teaching Scotland's Future. Edinburgh: Scottish Government. Retrieved from: http://www.gov.scot/Resource/Doc/337626/0110852.pdf Scottish Government. (2011b). Commission on the future delivery of public services. Edinburgh: Scottish Government. Retrieved from: http://www.scotland.gov.uk/Resource/Doc/352649/0118638.pdf Scottish Government. (2012). Getting it Right for Every Child. Edinburgh: Scottish Government. Retrieved from: http://www.gov.scot/Resource/0041/00417256.pdf Scottish Government. (2016). Introducing The Scottish Index of Multiple Deprivation 2016. A National Statistics publication for Scotland. Retrieved from: http://www.gov.scot/Resource/0050/00504809.pdf Scottish Educational Research Association. (2005). Ethical Guidelines for Educational Research. Retrieved from: http://www.sera.ac.uk/documents/Publications/SERA\%20Ethical\%20GuidelinesWeb.PDF Sosu, E, and Ellis, S., (2014). Closing the Attainment Gap in Scottish Education. Retrieved from: https://www.jrf.org.uk/sites/default/files/jrf/migrated/files/education-attainment$\underline{\text { scotland-full.pdf }}$

Thomson, P. (2015). Poverty and Education. Forum, 57(2), 205-207. 
Wang, J. (2001). Contexts of mentoring and opportunities for learning to teach: a

comparative study of mentoring practice. Teaching and Teacher Education, 17, 51-73.

Table 1: Social Capital Analytical Framework following Forbes and McCartney 2010

\begin{tabular}{|c|c|}
\hline $\begin{array}{l}\text { Key Features of } \\
\text { Social Capital }\end{array}$ & Descriptors \\
\hline Networks & $\begin{array}{l}\text { Durable ties or social relationships of 'mutual acquaintance or } \\
\text { recognition' (Bourdieu 1986), which emerge through interactions } \\
\text { between the members of a group, defined through commonalities } \\
\text { which may include their geography, profession, religion or culture. }\end{array}$ \\
\hline Norms & $\begin{array}{l}\text { The (mostly unwritten) rules, values and expectancies that characterize } \\
\text { a network's members. These may be behavioural (requiring certain } \\
\text { actions) or affective (relating to how we feel about the network). }\end{array}$ \\
\hline $\begin{array}{l}\text { Trust and } \\
\text { reciprocity }\end{array}$ & $\begin{array}{l}\text { The necessary mutual regard amongst members of a network required } \\
\text { for it to function cooperatively. }\end{array}$ \\
\hline $\begin{array}{l}\text { Sub-categories of } \\
\text { Social Capital }\end{array}$ & Descriptors \\
\hline $\begin{array}{l}\text { Bonding social } \\
\text { capital }\end{array}$ & $\begin{array}{l}\text { Characterized by strong bonds, e.g., among family members or among } \\
\text { members of an ethnic group; good for 'getting by'. ONS }(2002, \text { p. } 3)\end{array}$ \\
\hline $\begin{array}{l}\text { Bridging social } \\
\text { capital }\end{array}$ & $\begin{array}{l}\text { Characterized by weaker, less dense but more cross-cutting ties, e.g., } \\
\text { with business associates, acquaintances, friends from } \\
\text { different ethnic groups, friends of friends, etc.; good for 'getting } \\
\text { ahead'. ONS }(2002, \text { p. } 3)\end{array}$ \\
\hline $\begin{array}{l}\text { Linking social } \\
\text { capital }\end{array}$ & $\begin{array}{l}\text { Characterized by connections between those within a hierarchy where } \\
\text { there are differing levels of power. It is different from bonding and } \\
\text { bridging in that it is concerned with relations between people who are } \\
\text { not on an equal footing. ONS }(2002, \mathrm{p} 3)\end{array}$ \\
\hline $\begin{array}{l}\text { Levels of Social } \\
\text { Capital }\end{array}$ & Descriptors \\
\hline Macro & $\begin{array}{l}\text { Relating to national policy and governance e.g. GIRFEC (Scottish } \\
\text { Government, 2012) }\end{array}$ \\
\hline Meso & $\begin{array}{l}\text { Relating to school, community or other educational site (including } \\
\text { other interagency networks). }\end{array}$ \\
\hline Micro & $\begin{array}{l}\text { Relating to individual practitioners (including other children's services } \\
\text { practitioners). }\end{array}$ \\
\hline
\end{tabular}


Table 2: Summary background to the research participants and their perceptions of their practicum school.

\begin{tabular}{|l|l|l|l|}
\hline Participant & $\begin{array}{l}\text { Type of } \\
\text { School / } \\
\text { Department }\end{array}$ & SIMD Ranking & $\begin{array}{l}\text { Participant's view of the practicum } \\
\text { school. }\end{array}$ \\
\hline Amelia & $\begin{array}{l}\text { Secondary } \\
\text { - Modern } \\
\text { Languages }\end{array}$ & $\begin{array}{l}\text { 1682 (Most } \\
\text { deprived 25\%) }\end{array}$ & $\begin{array}{l}\text { "I didn't really know much about the } \\
\text { area...but looking at the housing and } \\
\text { everything, it looked like a deprived } \\
\text { area." }\end{array}$ \\
\hline Elsa & Primary & $\begin{array}{l}1322 \text { (Most } \\
\text { deprived 25\%) }\end{array}$ & $\begin{array}{l}\text { "The school was in a very built up area } \\
\text { that did include quite a nice area" }\end{array}$ \\
\hline Kyla & $\begin{array}{l}\text { Secondary - } \\
\text { English }\end{array}$ & $\begin{array}{l}\text { 2679 (Most } \\
\text { deprived 40\%, } \\
\text { but 21\% of } \\
\text { pupils live in } \\
\text { SIMD1\&2) }\end{array}$ & $\begin{array}{l}\text { "It was a rather old school... The layout } \\
\text { of the school is not the best for pupils } \\
\text { particularly with the challenging needs } \\
\text { they have. A high proportion of children } \\
\text { are in SIMD 1 and 2." }\end{array}$ \\
\hline Mary & Primary & $\begin{array}{l}1648 \text { (Most } \\
\text { deprived 25\%) }\end{array}$ & $\begin{array}{l}\text { "It's an urban school in a deprived area. } \\
\text { There's a lot of unemployment, and } \\
\text { kids are coming from backgrounds of } \\
\text { alcohol or drugs and there's a lot who } \\
\text { have English as second language." }\end{array}$ \\
\hline Rita & Primary & $\begin{array}{l}\text { 1534 (Most } \\
\text { deprived 25\%) }\end{array}$ & $\begin{array}{l}\text { "The school is right in the middle of } \\
\text { social housing which was very much in } \\
\text { a socially deprived area." }\end{array}$ \\
\hline
\end{tabular}


Table 3: Summary of the explicative themes

\begin{tabular}{|c|c|}
\hline Explicative Theme & Illustration \\
\hline $\begin{array}{l}\text { More challenging } \\
\text { than expected }\end{array}$ & $\begin{array}{l}\text { "I think it was more challenging in some respects because you think } \\
\text { you can help everyone, but you can't." (Kayla) }\end{array}$ \\
\hline $\begin{array}{l}\text { Notice situational } \\
\text { characteristics }\end{array}$ & $\begin{array}{l}\text { "We had so many kids with difficulties. In other schools there may } \\
\text { only be two or three, so you would have had a lot of input as to how to } \\
\text { manage them, but I think in every class in this school there was so } \\
\text { many." (Mary) }\end{array}$ \\
\hline $\begin{array}{l}\text { Encounter situational } \\
\text { practices }\end{array}$ & $\begin{array}{l}\text { "The breakfast club. That's the first thing I saw, I think because they } \\
\text { were looking at the fact that if you're not getting fed then that's going } \\
\text { to affect you for the rest of the day." (Rita) }\end{array}$ \\
\hline $\begin{array}{l}\text { Experience cultural } \\
\text { dissonance }\end{array}$ & $\begin{array}{l}\text { "We were handing out letters one day and one of the mums asked me } \\
\text { what it said, so I just read it to her. I knew that from then on I could } \\
\text { say to her 'look there's something in the bag, it's about this, this and } \\
\text { this...' and she would say 'that's fine, I'll speak to so and so and she'll } \\
\text { help me out with it.' (Rita) }\end{array}$ \\
\hline $\begin{array}{l}\text { Initiate a } \\
\text { pedagogical } \\
\text { response }\end{array}$ & $\begin{array}{l}\text { "If possible don't ability group them because they end up in ability } \\
\text { groups and all the kids that are living in poverty are at the same table } \\
\text { doing the easier work." (Elsa) }\end{array}$ \\
\hline $\begin{array}{l}\text { Value positive } \\
\text { relationships }\end{array}$ & "Building relationships is really important." (Kayla) \\
\hline $\begin{array}{l}\text { Seeking wider social } \\
\text { relations beyond the } \\
\text { classroom }\end{array}$ & $\begin{array}{l}\text { "It's talking to people who are working with the kids, not necessarily } \\
\text { the teachers but support staff or maybe community staff that work with } \\
\text { the school." (Kayla) }\end{array}$ \\
\hline $\begin{array}{l}\text { Reflecting on } \\
\text { practice }\end{array}$ & $\begin{array}{l}\text { "I think really trying to understand the needs of each pupil, their family } \\
\text { social background, yeah that's really important." (Amelia) }\end{array}$ \\
\hline
\end{tabular}


Table 4 Mapping features of social capital to explicative themes

\begin{tabular}{|c|c|}
\hline $\begin{array}{l}\text { Features of social capital } \\
\text { evident in student teachers' } \\
\text { lived experiences of practicum }\end{array}$ & Link to Explicative Themes \\
\hline Norms & $\begin{array}{l}\text { Theme 'notice situational characteristics' } \\
\text { Theme 'initiate a pedagogical response' }\end{array}$ \\
\hline Trust and reciprocity & Theme 'value positive relationships' \\
\hline Macro (Bridges) & $\begin{array}{l}\text { Theme 'seek wider social relations beyond the } \\
\text { classroom' }\end{array}$ \\
\hline Macro (Links ) & Theme 'more challenging than expected' \\
\hline Meso (Bridges) & $\begin{array}{l}\text { Theme 'seek wider social relations beyond the } \\
\text { classroom' }\end{array}$ \\
\hline Meso (Links) & Theme 'value positive relationships' \\
\hline Micro (Bridges) & $\begin{array}{l}\text { Theme 'seek wider social relations beyond the } \\
\text { classroom' }\end{array}$ \\
\hline Micro (Links) & $\begin{array}{l}\text { Theme 'encounter situational practices' } \\
\text { Theme 'seek wider social relations beyond the } \\
\text { classroom' }\end{array}$ \\
\hline
\end{tabular}

